\title{
Tingkah Laku Seksual Pejantan dan Induk Sapi Peranakan Ongole dengan Sistem Perkandangan Koloni Terbatas
}

\section{(Sexual Behavior of Ongole Crossbred Bull and Cow Kept in Intermitten Colony Housing System)}

\author{
Baliarti $\mathrm{E}^{1}$, Panjono ${ }^{1}$, Widi $\mathrm{TSM}^{1}$, Yulianto, $\mathrm{DEY}^{1}$, Ali $\mathrm{MH}^{1}$, Atmoko $\mathrm{BA}^{1}$, Maulana $\mathrm{H}^{1}$, \\ Effendhy $\mathrm{J}^{1}$, Prihandini $\mathrm{PW}^{2}$, Pamungkas $\mathrm{D}^{2}$ \\ ${ }^{1}$ Fakultas Peternakan, Universitas Gadjah Mada, Jl. Fauna No 3, Kampus UGM, Yogyakarta, 55281 \\ ${ }^{2}$ Loka Penelitian Sapi Potong, Jl. Pahlawan Grati, Pasuruan, Jawa Timur, 67184 \\ Bali_arti@ugm.ac.id
}

\begin{abstract}
This study aimeds to find out the sexual behavior of Ongole Crossbred (PO) bull and cows kept in intermittent colony housing system on smallholder farmers. One head of a bull and four head of cows were kept in intermittent colony housing system. Sexual behavior of bull observed were oro-nasal contact, flehmen, mounts response, and services. Sexual behavior of cows observed were mounting, standing to be installed, and mucus secretion. The sexual behavior observation of bull was carried out in all phases of the estrus cycle and cows were observed only in the estrus phase. Estrus was determined by observation of the vaginal epithelial cells. The data were analyzed descriptively. The results showed that there was a significant increase in all parameters of bull sexual behavior during the estrus period $(\mathrm{P}<0.05)$. The cows showed sexual behavior and characteristics of right conditions on vulva during estrus. All cows (100\%) had mounting behavior and remove mucus in their vulva. Increased intensity of bull sexual behavior during the period of the estrus was followed by the appearance of signs of estrus in the cows. PO bull kept in a intermittent colony with the cows showed higher sexual behavior during the cows in the estrus phase and followed by the appearance of behavior and estrus characteristics in the cows.
\end{abstract}

Key words: Sexual behavior, Ongole grade cattle, housing system, estrus phase

\begin{abstract}
ABSTRAK
Penelitian ini bertujuan untuk mengetahui tingkah laku seksual pejantan dan induk sapi Peranakan Ongole (PO) yang dipelihara secara koloni terbatas. 1 ekor pejantan dan 4 ekor induk sapi PO dipelihara secara berkoloni terbatas (diumbar bersama selama 1 jam, selanjutnya dikandangkan secara individu). Pengamatan tingkah laku seksual dilakukan secara langsung pada pejantan yaitu oro-nasal contact, flehmen, mounts orientation response, dan service. Tingkah laku seksual induk meliputi mounting, stand to be mounted dan karakteristik vulva. Pengamatan tingkah laku seksual pejantan dilakukan pada seluruh fase siklus estrus induk, pada induk hanya pada fase estrus. Penentuan fase siklus estrus dilakukan dengan melihat perubahan karakter dari sel epitel vagina ternak. Data dianalisis secara deskripsi kauntitatif. Terjadi peningkatan yang signifikan $(\mathrm{P}<0,05)$ pada seluruh parameter tingkah laku seksual pejantan selama fase estrus. Induk menunjukkan tingkah laku seksual dan karakteristik vulva yang baik selama estrus, induk (100\%) menunjukan tingkah laku mounting dan mengeluarkan lendir. Peningkatan intensitas tingkah laku seksual pejantan selama fase estrus induk diikuti oleh munculnya tanda-tanda estrus pada induk. Pejantan sapi PO yang dipelihara secara koloni terbatas bersama induk menujukkan tingkah laku seksual yang lebih
\end{abstract}


tinggi selama induk dalam fase estrus yang diikuti oleh munculnya tingkah laku dan tandatanda estrus.

Kata kunci: Tingkah laku seksual sapi PO, kandang koloni, siklus estrus

\section{PENDAHULUAN}

Perkawinan berulang pada induk sapi PO masih menjadi kendala di peternak rakyat, sehingga berdampak pada rendahnya kinerja reproduksi induk. Kelemahan pemahaman peternak dalam mendeteksi estrus menjadi salah satu penyebab terjadinya kawin berulang. Faktor lainnya adalah konsumsi nutrien induk yang masih dibawah standar kecukupan nutrien (Baliarti et al. 2018). Induk yang mengalami kekurangan nutrien akan kesulitan dalam mengekspresikan tingkah laku seksual akibat dari rendahnya sekresi hormon-hormon reproduksi (Rensis \& Scaramuzzi 2003). Hasil kajian Schuller et al. (2016) menunjukkan bahwa penggunaan pejantan dapat meningkatkan keberhasilan perkawinan. Pejantan dapat meminimalkan silent heat atau abnormalitas tingkah laku estrus ternak yang disebabkan oleh kekurangan nutrien pada induk.

Penggunaan pejantan sebagai biostimulan estrus pada induk di peternak rakyat masih jarang ditemukan. Pejantan secara umum dapat berperan untuk merangsang munculnya estrus, mendeteksi adanya estrus pada induk yang mengalai gangguan berahi tenang (silent heat), dan mengawini induk yang estrus secara alami sehingga tingkat keberhasilan perkawinan tinggi. Cara ini dirasa paling tepat dapat diaplikasikan di kelompok ternak atau peternakan rakyat untuk mengatasi permasalahan rendahnya kinerja reproduksi induk seperti panjangnya post-partum estrus (PPE), adanya berahi tenang, dan rendahnya keberhasilan perkawinan (S/C tinggi). (Baliarti et al. 2017; Atmoko et al. 2019).

Pemanfaatan pejantan sebagai stimulan pada kelompok ternak diharapkan dapat memunculkan estrus dan sebagai detektor adanya estrus pada induk. tanda-tanda estrus tersebut akan berpengaruh pada ketepatan dalam menentukan perkawinan atau dengan kata lain ketepatan perkawinan dipengaruhi oleh ketepatan deteksi estrus. Deteksi estrus dapat dilakukan dengan memperhatikan tanda-tanda yang dimunculkan oleh ternak. Richard (2015) menyatakan bahwa, pada umumnya sapi betina memunculkan tanda-tanda estrus seperti vulva memerah, membengkak dan mengeluarkan lendir bening. Namun tanda-tanda estrus tidak selalu muncul seluruhnya, terkadang hanya muncul sebagian atau bahkan tidak sama sekali. Baliarti et al. (2018) melaporkan bahwa tanda-tanda estrus induk yang dipelihara di kelompok peternakan rakyat antara lain adalah vulva berlendir (100\%), vulva berwarna merah $(71,42 \%)$, vulva membengkak $(57,14 \%)$ dan berlaku agresif dan gelisah (57,14\%), dan melenguh (42,85\%).

Tanda-tanda estrus tidak hanya diketahui melalui perubahan penampakan vulva, induk menunjukkan tingkah laku spesifik terkait fase reproduksi. Tingkah laku ditunjukkan pada saat menjelang, saat dan setelah estrus. Tingkah laku induk pada saat berahi antara lain urinasi, mengangkat ekor, melenguh, menaiki ternak lain, dan diam saat dinaiki ternak lain (Layek et al. 2011). Secara signifikan itngkah laku induk sapi di kelompok peternakan rakyat mempunyai tingkah laku yang berbeda signifikan pada saat estrus dengan tidak estrus, antara lain adalah frekuensi dan lama makan, frekuensi dan lama ruminansi lebih kecil (Baliarti et al. 2018)

Induk selain menunjukkan tingkah laku tersebut juga secara kontinyu menghasilkan senyawa feromon yang menarik perhatian sapi pejantan. Sapi pejantan mampu menangkap sinyal yang berasal dari induk kemudian merespon hal tersebut. Sinyal tersebut berupa feromon yang dapat berasal dari darah (Klemm et al. 1994), susu 
(Bendall 2001), urin (Ramesh et al. 2000), dan feses (Sankar \& Archunan 2006). Pejantan menunjukkan ekspresi perilaku yang spesifik pada saat induk estrus. Perilaku seksual tersebut antara lain mendekati betina, mengendus bagian genitalia betina, menaiki, dan mengawini (Shahhosseini 2013).

Kajian mengenai penggunaan pejantan dalam sistem pemeliharaan induk di peternak rakyat akan memberikan informasi yang dapat digunakan sebagai pertimbangan dalam penerapan sistem pemeliharaan dan perkawinan yang tepat. Penelitian ini ingin melihat perubahan tingkah laku seksual pejantan terhadap induk yang dipelihara secara koloni terbatas. Tujuan lain dari penelitian ini adalah melihat tingkah laku seksual yang diekspresikan oleh induk selama masa estrus akibat oleh adanya pejantan dalam pemeliharaan koloni terbatas.

\section{MATERI DAN METODE}

Penelitian dilakukan di kelompok ternak Mergo Andhini Makmur (MAM), Sleman, Daerah Istimewa Yogyakarta pada bulan Februari sampai September 2018. Penelitian menggunakan 1 ekor sapi PO pejantan dengan berat $500 \mathrm{~kg}$ dan 4 ekor sapi PO induk dengan berat rata-rata $300 \mathrm{~kg}$.

Ternak dipelihara secara koloni terbatas, yaitu diumbar bersama selama 1 jam setiap harinya dan kemudian dikandangkan secara individu. Pemberian pakan dan air minum berdasarkan program sehari-hari yang dilakukan oleh peternak tanpa ada intervensi dan perlakuan.

\section{Penentuan fase-fase estrus}

Penentuan fase estrus dilakukan dengan menganalisa kondisi sel-sel epitel vagina. Pengambilan vaginal smear dilakukan setiap 24 jam. Pengambilan sel-sel epitel vagina menggunakan cotton bud, kemudian dioleskan pada object glass. Object glass lalu direndam pada larutan alkohol selama 10 menit, kemudian di rendam pada larutan giemsa 3\% selama 40 menit. Sel-sel epitel vagina diamati menggunakan mikroskop dengan perbesaran 40 kali sebanyak 15 titik dari 3 ulasan pada object glass. Adapun karakteristik sel yang menjadi acuan penentuan fase-fase estrus adalah parabasal cell, intermediate cell dan superficial cell.

Tabel 1. Persentase tipe sel epitel vagina sebagai dasar penentuan fase estrus pada induk sapi PO

\begin{tabular}{lcccc}
\hline \hline \multirow{2}{*}{ Fase } & \multirow{2}{*}{ Durasi (hari) } & \multicolumn{3}{c}{ Proporsi sel epitel vagina (\%) } \\
\cline { 3 - 5 } & & Parabasal & Intermediate & Superficial \\
\hline Proestrus & $2-3$ & 37,64 & 43,95 & 18,41 \\
Estrus & $1-2$ & 20,93 & 32,60 & 46,49 \\
Metestrus & $3-4$ & 32,44 & 44,62 & 22,94 \\
Diestrus & $10-12$ & 48,43 & 37,18 & 14,40 \\
\hline
\end{tabular}

Studi tentang sitologi vagina sebagai alat yang berguna untuk deteksi estrus dan fase estrus pada beberapa spesies dan breed hewan. Sitologi vagina menunjukkan variasi dalam persentase sel epitel yang diamati selama penelitian untuk memprediksi estrus. Adapun karakteristik sel yang menjadi acuan penentuan fase-fase estrus adalah sel 
parabasal, intermediate dan superficial. Hasil pengamatan sitologi vagina disajikan pada tabel 1. Pengamatan yang diperoleh pada tabel 1 menunjukkan perbedaan pada setiap jenis sel pada setiap fase estrus. Pada fase non-estrus, sel parabasal dan intermediate mendominasi, dan tidak ada sel superfisial yang ditemukan. Perubahan mulai terjadi pada fase estrus dengan sel-sel superfisial meningkatkan persentase dan mendominasi. Perubahan komposisi yang terjadi pada sel parabasal dan sel superficial dapat digunakan sebagai indikator dalam menentukan fase ester dan sel superfisial merupakan indikator utama penentuan fase estrus pada waktu estrus, sel-sel superfisial mendominasi.

\section{Tingkah laku seksual}

Data yang diambil adalah tingkah laku seksual pejantan dan tingkah laku seksual induk. Pengamatan tingkah laku seksual dilakukan selama ternak diumbar bersama dengan bantuan alat kamera CCTV bermerek Hikvision ${ }^{\mathrm{TM}}$ dengan kualitas gambar 1080p.

Tabel 2. Deskripsi tingkah laku seksual pejantan yang diamati

\begin{tabular}{ll}
\hline \hline Tingkah laku & \multicolumn{1}{c}{ Deskripsi } \\
\hline $\begin{array}{l}\text { Oro-nasal contact } \\
\text { (ONC) }\end{array}$ & $\begin{array}{l}\text { Stimulus yang dicirikan dengan mengendus, menyundul atau } \\
\text { menjilat bagian vulva. } \\
\text { Flehmen }\end{array}$ \\
$\begin{array}{l}\text { Mengendus daerah alat kelamin betina kemudian menarik bibir } \\
\text { bagian atas atau menyengir }\end{array}$ \\
$\begin{array}{l}\text { Mounts orientation } \\
\text { Gesponse (MOR) }\end{array}$ & $\begin{array}{l}\text { seringkali diawali dengan meletakkan kepala pada punggung betina } \\
\text { Posisi pejantan menaiki induk yang dicirikan dengan kedua kaki } \\
\text { depan pejantan terangkat sepenuhnya dari lantai }\end{array}$ \\
Services & Menaiki betina yang disusul dengan kopulasi \\
\hline
\end{tabular}

Sumber: Garcia et al. (1986)

Tabel 3. Deskripsi tingkah laku seksual dan karakteristik vulva induk yang diamati

\begin{tabular}{|c|c|}
\hline Parameter & Deskripsi \\
\hline \multicolumn{2}{|l|}{ Tingkah laku seksual } \\
\hline Mounting & $\begin{array}{l}\text { Respon menaiki ternak lain ditunjukkan oleh induk baik kepada } \\
\text { pejantan maupun induk lainnya }\end{array}$ \\
\hline $\begin{array}{l}\text { standing to be Mounted } \\
\text { (STBM) }\end{array}$ & $\begin{array}{l}\text { Saat induk menerima dinaiki oleh ternak lain atau pejantan, } \\
\text { induk saat STBM tidak berarti diam sepenuhnya, seringkali } \\
\text { bergerak maju karna beban yang diterima }\end{array}$ \\
\hline \multicolumn{2}{|l|}{ Karakteristik vulva } \\
\hline Reddening vulva, & $\begin{array}{l}\text { Munculnya perubahan warna kemerah-merahan dengan } \\
\text { membandingkan pada saat tidak estrus }\end{array}$ \\
\hline Swelling vulva & $\begin{array}{l}\text { Adanya kebengkakan pada vulva dengan membandingkan pada } \\
\text { saat tidak estrus }\end{array}$ \\
\hline Mucuse secretion & Adanya sekresi lendir bening \\
\hline
\end{tabular}

Sumber: (Garcia et al. 1986) 
Tingkah laku pejantan yang diamati meliputi frekuensi Oro-nasal contact (ONC), Flehmen, Mounts orientation response (MOR), Mounts, dan Services yang dideskripsikan pada Tabel 2. Tingkah laku induk yang diamati yaitu menaiki mounting, standing to be Mounted (STBM), dan karakteristik visual vulva, meliputi reddening vulva, swelling vulva, mucuse secretion yang dideskripsikan pada Tabel 3.

\section{Analisis data}

Tingkah laku seksual pejantan pada fase proestrus, estrus metestrus, dan diestrus dihitung rata-rata dan standar deviasinya untuk disajikan secara deskriptif kuantitatif. Sedangkan data tingkah laku seksual induk dihitung persentasenya untuk disajikan secara deskriptif kuantitatif.

\section{HASIL DAN PEMBAHASAN}

\section{Tingkah laku seksual pejantan}

Pejantan memberikan respon seksual bervariasi terhadap induk dalam berbagai fase estrus pada induk (Tabel 4). Tingkah laku yang terjadi merupakan respon terhadap induk yang mulai memberikan sinyal yang mana kemudian ditangkap oleh pejantan.

Pada fase proestrus, pejantan menunjukkan tingkah laku seksualnya berupa respon ONC, Flehmen dan MOR. Respon tingkah laku seksual pejantan tersebut tidak terlepas dari daya tarik (attractivity) berupa stimulus behavioral dan non behavioral betina yang mempengaruhi respon pejantan (Denver 2003).

Tabel 4. Rata-rata dan standar deviasi tingkah laku seksual pejantan sapi Peranakan Ongole (PO) pada sistem perkandangan koloni terbatas

\begin{tabular}{lcccc}
\hline \hline \multirow{2}{*}{ Parameters } & \multicolumn{4}{c}{ Fase } \\
\cline { 2 - 5 } & Proestrus & Estrus & Metestrus & Diestrus \\
\hline Oro-nasal contact (kali) & $3,50 \pm 2,65$ & $16,00 \pm 10,03$ & $3,75 \pm 6,18$ & $0,75 \pm 0,96$ \\
Flehmen (kali) & $2,00 \pm 1,41$ & $7,00 \pm 2,45$ & $2,00 \pm 4,00$ & $0,50 \pm 0,58$ \\
Mounts orientation response (kali) & $0,25 \pm 0,50$ & $35,00 \pm 25,50$ & & \\
Services (kali) & & $4,00 \pm 3,56$ & \\
\hline
\end{tabular}

Fase estrus merupakan fase dimana induk menerima perkawinan oleh pejantan, pada fase ini pula respon tingkah laku seksual pejantan muncul secara keseluruhan. Respon

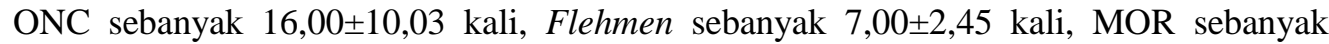

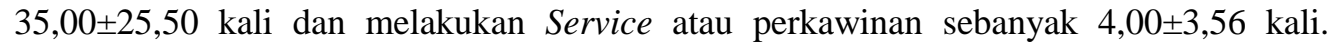
Respon tingkah laku seksual yang ditunjukkan oleh pejantan pada penelitian ini sesuai dengan penelitian-penelitian terdahulu yang menyebutkan bahwa pada saat induk estrus pejantan memberi respon ONC (Solano et al. 2005), Flehmen (Denvic Le et al. 2015; Sankar \& Archunan 2004), MOR (Campbell et al. 2004), Mounts (Richard 2015), dan Services (Denver 2003). Dengan demikian salah satu fungsi pejantan sebagai stimulan di kandang koloni atau berkelompok yaitu dapat melakukan service atau mengawini induk yang dalam kondisi estrus. Tingkah laku seksual pejantan terhadap induk pada fase estrus menunjukkan paling tinggi secara signifikan dibandingkan pada saat induk dalam fase non estrus. 
Pasca masa estrus berakhir dalam rentan waktu 24 jam atau memasuki phase metestrus menunjukan bahwa respon tingkah laku seksual pejantan terhadap induk adalah ONC dan Flehmen. Respon tersebut juga dimunculkan oleh pejantan setelah masa estrus betina yang meliputi ONC (Garcia et al. 1986) dan Flehmen (Sankar \& Archunan 2004).

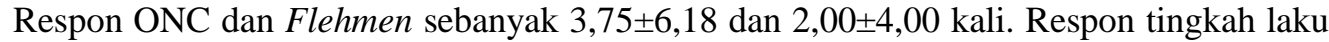
seksual pada fase diestrus ditemui respon ONC dan Flehmen masing-masing sebanyak

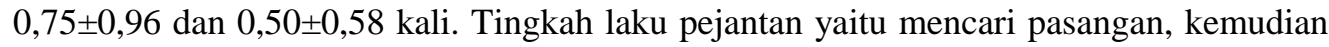
melakukan pendekatan dan investigasi (Denver 2003). Investigasi melalui olfactory molecules yang memberikan petunjuk fase siklus estrus induk dan menstimulasi tingkah laku seksual dan fungsi endokrin pejantan (Vyas et al. 2012). Hasil menunjukkan bahwa tidak ada keberlanjutan respon pejantan, dimana pejantan tidak lagi memberi perhatian terhadap induk diestrus. Hal ini sesuai dengan pendapat Senger (2012) yang menyatakan bahwa pejantan secara konstan mencari dan mengidentifikasi induk untuk mengetahui apakah induk menerima secara seksual atau tidak.

Sapi pejantan secara alami menunjukkan tingkah laku yang berbeda terhadap siklus estrus betina. Ekspresi tingkah laku pejantan terhadap betina estrus secara visual dapat diamati. Shahhosseini (2013) menyatakan bahwa, hormon mempengaruhi tingkah laku ternak. Vyas et al. (2012) menyatakan bahwa terdapat senyawa kimia atau feromon yang dihasilkan oleh betina, senyawa tersebut menjadi petunjuk bahwa betina memasuki fase estrus, kemudian pejantan mampu menangkap bau yang spesifik tersebut dan menstimulus pejantan dengan munculnya tanda-tanda tingkah laku seksual.

\section{Tingkah laku seksual karakteristik vulva induk estrus}

Tingkah laku seksual sekunder yang ditunjukkan oleh induk salah satunya adalah menaiki ternak lainnya (Yager 2017). Hasil penelitian Layek et al. (2011) didapatkan 96\% induk dari populasi menunjukkan respon tersebut. Pada penelitian tidak ditemui perilaku tersebut (Tabel 5). Hasil ini dapat disebabkan oleh berbagai faktor. Respon menaiki ternak lain sangat dipengaruhi oleh jumlah ternak yang berada pada fase estrus dan hirarki sosial dalam satu kawanan tersebut. Pemeliharaan berkoloni secara terbatas atau tidak secara penuh terus-menerus menyebabkan tingkah laku tersebut belum diekspresikan. Respon STBM merupakan salah satu perilaku yang paling akurat untuk menunjukkan bahwa ternak dalam fase estrus (Michael 2019). Induk secara keseluruhan (100\%) menunjukkan tingkah laku tersebut. Hasil tersebut lebih tinggi dibandingkan penelitian yang dilakukan oleh Layek et al. (2011) yaitu 98\% dari keseluruhan populasi induk estrus. Hal tersebut dapat disebabkan oleh perbedaan jumlah induk yang digunakan dalam penelitian.

Perubahan penampakan vulva pada saat berahi tidak seluruhnya muncul pada pemeliharaan secara terbatas ini. Baliarti et al. (2018), melaporkan bahwa tanda-tanda estrus induk sapi PO yang dipelihara di kelompok peternakan rakyat antara lain adalah vulva berlendir (100\%), vulva berwarna merah (71,42\%), vulva membengkak $(57,14 \%)$ dan berlaku agresif dan gelisah (57,14\%), dan melenguh (42,85\%) sedangkan Syahriyah (2014) menyatakan bahwa sapi PO memiliki tanda visual berahi berupa vulva memerah 100\%, membengkak 33,33\% dan mengeluarkan lendir 100\%. Tanda-tanda perubahan warna vulva dan vulva membengkak sebesar 50\%, dan keluarnya lendir (100\%) ditemui pada semua induk. 
Tabel 5. Persentase tingkah laku seksual dan karakteristik vulva induk sapi Peranakan Ongole (PO) dalam fase estrus dengan sistem perkandangan koloni terbatas

\begin{tabular}{lc}
\hline \hline Parameter & Jumlah persentase (\%) induk \\
\hline Mounting & 100 \\
Stand to be mounted & 100 \\
Reddening vulva & 50 \\
Swelling vulva & 50 \\
Sekresi lendir (\%) & 100 \\
\hline
\end{tabular}

Saara et al. (2011) menyatakan bahwa kenaikan level estrogen berhubungan dengan memerah dan membengkaknya vulva saat berahi yang merangsang aliran darah ke saluran reproduksi dan organ genital terkait. Frandson et al. (2009) menyatakan bahwa meningkatnya sekresi lendir diawali dengan penebalan dinding vagina dan peningkatan vaskularsasi oleh rangsangan hormon estrogen. Kondisi tersebut menyebabkan perubahan kondisi vulva membengkak dan berwarna merah. Tingkah laku seksual induk dipengaruhi oleh kehadiran pejantan sebagai stimulator. Hemsworth (2007) menyatakan bahwa induk yang tidak menunjukkan tanda-tanda berahi kemudian dipelihara bersama dengan pejantan akan memunculkan tanda-tanda tersebut.

Produksi hormon mempengaruhi fisiologis tubuh ternak, pada induk estrus antara lain mempengaruhi bau dan tampak luar tubuh yang mengalami perubahan (Shahhosseini 2013). Adanya pejantan memberi efek biostimulatsi pada betina yang dapat mempengaruhi sexual maturity, terjadinya ovulasi dan menurunkan waktu yang dibutuhkan untuk mengembalikan fungsi organ reproduksi (Rekwot et al. 2000). Keberadaan pejantan terhadap betina juga mampu mempercepat munculnya berahi pertama pada sapi-sapi dara dan mempersingkat waktu post-partum (Baliarti et al. 2017).

\section{KESIMPULAN}

Disimpulkan bahwa pejantan sapi PO yang dipelihara secara koloni terbatas bersama dengan induk pada penelitian ini menujukkan tingkah laku seksual yang lebih tinggi selama induk dalam fase estrus dan diikuti oleh munculnya tingkah laku mounting, stand to be mounted dan ciri-ciri estrus berupa sekresi lendir pada induk.

\section{UCAPAN TERIMA KASIH}

Ucapan terima kasih disampaikan kepada Loka Penelitian Sapi Potong Grati atas kerjasamanya dengan Fakultas Peternakan UGM Tentang Kerjasama Pemanfaatan Pejantan Sapi Potong. Ucapan terima kasih juga disampaikan kepada peternak di Kelompok Ternak Mergo Andhini Makmur, Sleman.

\section{DAFTAR PUSTAKA}

Atmoko BA, Baliarti E, Fitriyanto NA. 2019. Iptek bagi masyarakat (IbM) melalui peningkatan panen pedet dan produksi kompos berkualitas pada kelompok ternak sapi potong. Indones J Commun Engagem. 5:72-98.

Baliarti E, Atmoko BA, Fitriyanto NA, Ibrahim A, Priambodo P, Prabowo BW. 2017. Penggunaan pejantan sebagai biostimulator di Kelompok Ternak Margo Andhini 
Makmur dalam rangka meningkatkan angka kebuntingan induk sapi Peranakan Ongole. Prosiding Seminar Nasional Peternakan 3. Makassar (Indonesia): Universitas Hasanuddin. hlm. 339-349.

Baliarti E, Priambodo P, Ismaya, Budiyanto A, Yulianto MDE, Atmoko BA. 2018. Pengamatan visual vulva dan perubahan behaviour sapi estrus pada pemeliharaan di tingkat peternak. Prosiding Seminar Teknologi dan Agribisnis Peternakan VI. Purwokerto. Purwokerto (Indonesia): Universitas Jendral Sudirman. hlm. 153-157.

Bendall JG. 2001. Aroma compounds of fresh milk from New Zealand cows fed different diets. J Agric Food Chemist. 49:4825-4832.

Campbell NA, Reece JB, Mitchell LG. 2004. Biologi. Edisi 5 Jilid III. Jakarta (Indonesia): Penerbit Erlangga.

Denver JB. 2003. An approach to the measurement of sexual behavior in the bull (Bos taurus) using variable female stimulus conditions [Disertasi]. Lexington (USA): University of Kentucky.

Denvic Le L, Gerand LO, Sellem E, Ponsart C, Chemineu P, Humblot P, Nagnan L, Meilour P. 2015. Enhancing bull sexual behavior using estrus-specific molecules identifiesd in cow urine. Theriogenology. 83:1381-1388.

Frandson RD, Lee Wilke W, Anna Dee Fails. 2009. Anatomy and physiologhy farm animals. Iowa (USA): Wiley-Blackwell.

Garcia MC, McDonnel SM, Kenney RM. 1986. Bull sexual behavior test: stimulus cow affects performance. Appl Anim Behav Sci. 16:1-10.

Hemsworth PH. 2007. Sexual behavior of male pigs. Hormones and Behavior. 52:39-44.

Klemm WRY, Rivard GF, Clement BA. 1994. Blood acetaldehyde fluctuates markedly during bovine estrous cycle. Anim Reprod Sci. 35:9-26.

Layek SS, Mohanty TK, Kumaresan A, Behera K, Chand S. 2011. Behavioural signs of estrus and their relationship to time of ovulation in Zebu (Sahiwal) cattle. Anim Reprod Sci. 129:140-145.

Michael GD. 2019. AI and heat detection in beef herds. Ireland: Teagasc.

Ramesh K, Archunan G, Jeyraman R, Narasimhan S. 2000. Chemical characterization of bovine urine with special reference to estrous cycle. Vet Res Commun. 24:445-454.

Rekwot PI, Ogwu D, Oyedipe EO. 2000. Influence of bull biostimulation, season and parity on resumption of ovarian activity of zebu (Bos indicus) cattle following parturition. Anim Reprod Sci. 63:1-11.

Rensis FD, Scaramuzzi RJ. 2003. Heat stress and seasonal effects on reproduction in the dairy cow-a review. Theriogenology. 60:1139-1151.

Richard MH. 2015. Bovine reproduction. Iowa (USA): John Wiley \& Sons, Inc.

Saara CS, Clark SG, Knox RV, Tamassia MA. 2011. Vulva skin temperature changes significantly during estrus in swine as determined by digital infrared thermograph. J Swine Health Prod. 19:152-157.

Sankar R, Archunan G. 2004. Flehmen response in bull: role of vaginal mucus and other body fluids of bovine with special reference to estrus. J Vet Sci Technol. 67:81-86.

Schuller LK, Burfeind O, Heuwieser W. 2016. Effect of short- and long-term heat stress on the conception risk of dairy cows under natural service and artificial insemination breeding programs. J Dairy Sci. 99:2996-3002. 
Senger PL. 2012. Pathways to pregnancy \& parturition. 3rd ed. Current Conceptions, United States: Inc. Redmond.

Shahhosseini Y. 2013. Cattle behavior. Uppsala (Swedia): Swedish University of Agricultural Sciences..

Solano J, Orihuela A, Galina CS, Montiel F, Galindo F. 2005. Relationship between social behavior and mounting activity of Zebu cattle (Bos indicus). Appl Anim Behav Sci. 94:197-203.

Syahriyah, F. 2014. Vaginal smear sebagai alat bantu deteksi estrus pada sapi peranakan ongole dan simmental peranakan ongole [Skripsi]. Yogyakarta (Indonesia): Universitas Gadjah Mada.

Vyas S, Briant C, Chemineau P, Le Danvic C, Nagnan-Le Meillour P. 2012. Oestrus pheromones in farm mammals, with special reference to cow. Ind J Anim Sci. 82:256267.

Yager A, Neary M, Singleton W. 2017. Estrus detection in farm animals. West Lafayette (United States): Purdue University. 